\title{
PENINGKATAN MINAT BELAJAR TEMATIK MUPEL IPA MELALUI PEMBELAJARAN KOOPERATIF TIPE SCRAMBLE SISWA KELAS 5 SDN SALATIGA 09 TAHUN PELAJARAN 2017/2018
}

\author{
Fachrul Imami ${ }^{1}$, Wasitohadi ${ }^{2}$, Theresia Sri Rahayu ${ }^{3}$ \\ 1Pendidikan Guru Sekolah Dasar, Universitas Kristen Satya Wacana, fachrul551@gmail.com \\ 2Pendidikan Guru Sekolah Dasar, Universitas Kristen Satya Wacana, wasitohadi@staff.uksw.edu \\ 3Pendidikan Guru Sekolah Dasar, Universitas Kristen Satya Wacana, th.rahayu@gmail.com
}

\section{INFO ARTIKEL}

RiwayatArtikel:

Diterima: 28-03-2018

Disetujui: 06-04-2018

\section{Kata Kunci:}

Model Scramble Minat Belajar

ABSTRAK

Abstrak: Tujuan penelitian ini untuk meningkatkan minat belajar tematik mupel IPA melalui pembelajaraan kooperatif tipe scramble. Penelitian dilaksanakan di SDN Salatiga 09 Kecamatan Sidorejo Kota Salatiga dengan subjek penelitian seluruh siswa kelas $V$ yang berjumlah 43 siswa. Data penelitian minat belajar siswa diperoleh melalui angket minat dan lembar evaluasi. Pada pra siklus persentasi minat belajar siswa sebesar 69,38\%, pada siklus I persentasi minat belajar siswa $72,40 \%$, dan pada siklus II persentasi minat belajar siswa 89,75\%. Dengan demikian disimpulkan bahwa melalui model pembelajaran kooperatif tipe scramble dapat meningkatkan minat belajar tematik mupel IPA siswa kelas V SDN Salatiga 09 tahun pelajaran 2017/2018.
\end{abstract}

IPA

\begin{abstract}
The purpose of this research is to improve the interest of thematic science mupel learning through cooperative type scramble learning. The research was carried out at SDN Salatiga 09 Sidorejo Sub-district Salatiga City with the subject of all V-student's students of 43 students. Student interest research data is obtained through interest questionnaire and evaluation sheet. In the pre cycles of the percentage of students' learning interest by $69.38 \%$, in the first cycle the percentage of students' learning interest is $72.40 \%$, and in the second cycle the percentage of students' learning interest is $89.75 \%$. Thus it is concluded that through cooperative learning model type scramble can increase interest in thematic science mupel student grade V SDN Salatiga 09 year lesson 2017/2018.
\end{abstract}

\section{A. LATAR BELAKANG}

Permendikbud RI nomer 57 tahun 2014 tentang kurikulum 2013 sekolah Dasar/Madrasah Ibtidiyah menyatakan bahwa pelaksanaan pembelajaran pada Sekolah Dasar/Madrasah dilakukan dengan pendekatan tematik-terpadu. Pembelajaran tematik-terpadu merupakan muatan pembelajaran dalam mata pelajaran Sekolah Dasar/Madrasah Ibtidaiyah yang diorganisasikan dalam tema-tema. Melalui penerapan pembelajaran tematik terpadu di sekolah dasar/madrasah ibtidaiyah menunjukkan bahwa penyampaian materi pembelajaran berbeda dengan kurikulum sebelumnya yaitu Kurikulum Satuan Tingkat Pendidikan (KTSP) yang dalam penyampaiannya mata pelajaran secara terpisah.

Oemar Hamalik (2017 : 158) menjelaskan bahwa kurikulum terintegrasi atau terpadu (Integreted Curriculum), batas-batas diantara semua mata pelajaran sudah tidak terlibat sama sekali. Semua mata pelajaran sudah dirumuskan dalam bentuk masalah satu unit. Pembelajran tematik terpadu dalam kurikulum 2013 perpaduan antara mata pelajaran dirumuskan dalam bentuk tema yang terdiri dari beberapa sub tema dan dalam satu subtema terdiri 6 pembelajaran.

Salah satu tema pembelajaran dalam kurikulum 2013 untuk kelas V SD adalah Lingkungan Sahabat Kita yang terdiri dari 3 subtema dan 6 pembelajaran salah satunya adalah sub tema Manusia dan Lingkungan pembelajaran ke 2. Subtema tersebut terdiri dari 3 mata pelajaran yaitu, Bahasa Indonesia, IPA, dan SBdP yang disampaikan oleh guru secara tematik terpadu sehingga batas-batas diantara mata pelajaran tidak terlihat sama sekali oleh siswa. Guru perlu memiliki strategi mengajar yang baik agar pembelajaran tematik terpadu dapat terlaksana dan tujuan pembelajaran dapat tercapai.

Dalam proses pembelajaran tematik guru harus mengerti bagaimana memberikan rangsangan sehingga siswa menyukai belajar tematik dan lebih memahami materi yang diberikan oleh guru, serta mampu mengantisipasi kemungkinan-kemungkinan munculnya kelompok siswa yang menunjukkan gejala kegagalan dengan berusaha mengetahui dan mengatasi faktor yang menghambat proses pembelajaran. Hal lain yang berperan dalam proses pembelajaran, adalah cara guru mengajar atau menyampaikan pelajaran. Penyampaian 
guru yang cenderung bersifat monoton, hampir tanpa variasi kreatif, ternyata sangat berpengaruh terhadap prestasi belajar. Hampir sebagian besar siswa takut dengan pelajaran tematik karena tematik dianggap sebagai momok. Seandainya siswa ditanya tentang tematik ada saja alasan yang mereka kemukakan seperti tematik sulit dan membosankan. Sehingga siswa kurang suka terhadap pelajaran tematik dan menyebabkan siswa malas untuk belajar tematik. Beda dengan guru yang kreatif dalam menyampaikan pelajaran. Guru berusaha merubah anggapan siswa bahwa pelajaran tematik sangat sulit dan membosankan menjadi menyenangkan dan menarik. Sehingga materi yang dipelajari akan lebih menarik dan membuat siswa merasa senang, aktif, dan penuh semangat dalam pembelajaran sehingga akan timbul perhatian terhadap materi tersebut dan diharapkan akan menumbuhkan minat dalam diri siswa. Melalui minat seseorang akan melakukan sesuatu yang akan dilakukannya, sebaliknya tanpa minat seseorang tidak akan melakukan sesuatu. Sama halnya semakin besar minat siswa terhadap pelajaran tematik maka semakin besar pula perhatiannya sehingga akan memperbesar hasrat dan kemauan untuk mempelajari tematik yang juga akan berpengaruh terhadap prestasi belajar pada diri siswa.

Dengan penerapan model pembelajaran yang tepat maka minat siswa terhadap pembelajaran itu akan meningkat sehingga hasil belajar juga akan lebih maksimal. Model dirancang untuk mewakili realitas sesungguhnya, walaupun model itu sendiri bukanlah realitas dari dunia sebenarnya. Sagala, S. (2003: 169) mengemukakan, model pembelajaran adalah cara yang digunakan guru dalam mengorganisasikan kelas pada umumnya atau dalam menyajikan bahan pelajaran pada khususnya.

Menurut Rober B. Taylor (2001), Scramble merupakan salah satu model pembelajaran yang dapat meningkatkan konsentrasi dan kecepatan berpikir siswa. Model ini mengharuskan siswa untuk menggabungkan otak kanan dan otak kiri. Dalam model ini, siswa tidak hanya diminta untuk menjawab soal, tetapi juga mereka dengan cepat mencari jawaban dari soal yang sudah tersedia namun masih dalam kondisi acak. Ketetapan dan kecepatan berpikir dalam menjawab soal menjadi salah satu kunci permainan model pembelajaran Scramble. Skor siswa ditentukan oleh seberapa banyak soal yang benar dan seberapa cepat soal-soal tersebut dikerjakan. Dalam model ini, semua siswa terlibat dalam kegiatan pembelajaran, tidak hanya siswa yang pintar saja yang aktif menjawab pertanyaan guru. Selain itu model pembelajaran Scramble juga dapat melatih kerja sama dan kedisiplinan, siswa dilatih untuk patuh terhadap aturan-aturan pembelajaran. Model pembeajaran ini dapat merangsang siswa berpikir kritis dan cepat.

Hasil observasi awal yang dilakukan terhadap proses pembelajaran tematik di kelas VI SDN Salatiga 09 diperoleh informasi bahwa selama proses pembelajaran, guru belum memberdayakan seluruh potensi dirinya dalam pembelajaran sehingga sebagian besar siswa belum mempuyai minat dalam belajar akibatnya mereka belum mampu mencapai kopetensi individual yang diperlukan untuk mengikuti pembelajaran selanjutnya. Siswa baru mampu menghafal fakta, kosep, prinsip, hukum, teori, dan gagasan inovatif lainnya pada tingkat ingatan dan penggunaan media pembelajaran juga masih kurang, sehingga hasil belajar kurang maksimal. Dengan menerapkan model scramble dalam menyampaikan pembelajaran tematik diharapkan siswa memiliki pengetahuan, pemahaman belajar lebih bermakna, mampu menghubungkan materi yang dipelajari dengan kehidupan nyata dan menumbuhkan kreatifitas sehingga meningkatkan minat siswa.

Berdasarkan latar belakang diatas, maka perlu dilakukan perbaikan proses pembelajaran melalui penelitian tindakan kelas dengan judul "Peningkatan Minat Belajar Tematik Tema 8 Pada Mupel IPA Melalui Pembelajaran Kooperatif Tipe Scramble Pada Siswa Kelas V SDN Salatiga 09 Tahun Pelajaran 2017/2018”

\section{B. KAJIAN PUSTAKA}

\section{Pengertian Tematik}

Pembelajaran tematik dimaknai sebagai pembelajaran yang dirancang berdasarkan tematema tertentu. Pembelajaran tematik menyediakan keluasan dan kedalaman implementasi kurikulum, menawarkan kesempatan yang sangat banyak pada siswa untuk memunculkan dinamika dalam pendidikan.

Pembelajaran tematik merupakan pendekatan pembelajaran yang mengintregatifkan berbagai kompetensi dan berbagai mata pelajaran ke dalam berbagai tema. Pengintegratifan tersebut dilakukan dalm dua hal, yaitu integratif sikap, keterampilan dan pengetahuan dalam proses pembelajaran dan integratif berbagai konsep dasar yang berkaitan. Tema merajut makna berbagai konsep dasar sehingga siswa tidak belajar konsep dasar secara parsial. Dengan demikian pembelajarannya memberikan makna yang utuh kepada siswa seperti tercermin pada berbagai tema yang tersedia (Kurniawati dan Wakhyudin, 2014: 60). Pembelajaran dengan pendekatan tematik, yang juga disebut dengan pembelajaran tematik, adalah pembelajaran yang melibatkan beberapa mata pelajaran, atau pembelajaran terpadu melalui tema (Pitadjeng, 2009: 88). Pendekatan tematik merupakan pendekatan dalm pembelajaran yang secara sengaja mengaitkan beberapa aspek bak dalam intra mata pelajaran mauoun antara mata pelajaran (Reffiane dan Saptaningrum, 2011: 43). Berdasarkan pemdapat para ahli tersebut dapat disimpulkan bahwa pembelajaran tematik merupakan pendekatan pembelajaran yang 
melibatkan beberapa mata pelajaran dengan sengaja dikaitkan dengan beberapa aspek dalam mata pelajaran dan terintegratif dalam kompetensi berbagai mata pelajaran ke dalam berbagai tema.

Menurut Kunandar (2007:311) Tema merupakan alat atau wadah untuk mengedepankan berbagai konsep kepada anak didik secara utuh. Dalam pembelajaran, tema diberikan dengan maksud untuk menyatukan isi kurikulum dalam satu kesatuan yang utuh, memperkaya perbendaharaan bahasa siswa dan membuat pembelajaran yang melibatkan beberapa mata pelajaran untuk memberikan pengalaman yang bermakna kepada siswa.

Prinsip-prinsip yang perlu diperhatikan dalam menerapkan dan melaksanakan pembelajaran tematik ( Suryobroto: 2009) yaitu:

a. Bersifat konstekstual atau terintegrasi dengan lingkungan pembelajaran yang dilakukan dikemas dalam suatu format keterkaitan, maksudnya pembahasan suatu topik dikaitkan dengan kondisi yang dihadapi siswa menemukan masalah dan memecahkan masalah yang nyata dihadapi siswa dalam kehidupan sehari-hari dikaitkan dengan topik yang dibahas.

b. Bentuk belajar dirancang agar siswa bekerja secara sungguh-sungguh untuk menemukan tema pembelajaran yang rill sekaligus mengaplikasikannya.

c. Efisiensi

Pembelajaran tematik memiliki nilai efisiensi antara lain dalam segi waktu, beban materi, metode, penggunaan sumber belajar yang otentik sehingga dapat mencapai ketuntasan kompetensi secara tepat.

Pembelajaran tematik memiliki ciri-ciri atau karakteristik seperti berikut ini:

a. Berpusat pada siswa

Proses pembelajaran yang dilakukan harus menempatkan siswa sebagai pusat aktivitas dan harus mampu memperkaya pengalaman belajar.

b. Memberikan pengalaman langsung kepada siswa agar pembelajaran lebih bermakna maka siswa perlu belajar secara langsung dan mengalami sendiri.

c. Permasalahan mata pelajaran tidak begitu jelas mengingat tema dikaji dari berbagai mata pelajaran dan saling berkaitan maka batas mata pelajaran menjadi tidak begitu jelas.

d. Menyajikan konsep dari berbagai mata pelajaran dalam suatu proses pembelajaran

e. Bersifat fleksibel

f. Pelaksanaan pembelajaran tematik tidak terjadwal secara ketat antar mata pelajaran

g. Hasil pembelajaran dapat berkembang sesuai dengan minat dan kebutuhan siswa.

\section{Model Pembelajaraan Kooperatif Tipe Scramble}

Menurut Suprihatiningrum (2013: 142), "model pembelajaran merupakan kerangka konseptual yang menggambarkan prosedur dalam mengorganisasikan pengalaman pembelajaran untuk mencapai tujuan pembelajaran.” Model pembelajaran berfungsi sebagai pedoman bagi guru dalam merencanakan dan melaksanakan kegiatan pembelajaran. Penggunaan model pembelajaran biasanya disesuaikan dengan tujuan pembelajaran yang akan dicapai oleh guru. Dengan model pembelajaran diharapkan tujuan pembelajaran dapat tercapai secara efektif dan mampu membuat siswa untuk berpikir kritis.

Salah satu model pembelajaran adalah model pembelajaran Kooperatif. Model pembelajaran Kooperatif adalah pembelajaran yang dirancang untuk saling bekerja sama. Menurut Hans (dalam Suprihatiningrum, 2013: 191), "pembelajaran kooperatif merupakan suatu cara pendekatan atau strategi yang dirancang khusus untuk memberi dorongan kepada siswa untuk bekerja sama dalam pembelajaran.” Dalam pembelajaran Kooperatif ini, siswa biasanya dibagikan kedalam kelompok, baik kelompok banyak maupun kecil. Melalui kerja kelompok tersebut siswa tidak hanya dituntut mengerti untuk dirinya sendiri, tetapi juga bertanggung jawab dalam pemahaman setiap anggota kelompoknya. Pembelajaran Kooperatif termasuk pembelajaran yang student oriented, berpusat pada siswa, sehingga siswa akan terlibat dalam pembelajaran.

Salah satu tipe model pembelajaran Kooperatif adalah Scramble. Menurut Huda (2013: 303), "model pembelajaran Scramble adalah pembelajaran yang dilakukan secara berkelompok dengan mencocokkan kartu pertanyaan dengan karrtu jawaban yang telah disediakan.” Dalam model ini terdapat dua kartu yang disediakan guru, yaitu kartu soal dan kartu jawaban yang diacak. Model ini tidak hanya menuntut siswa dapat menjawab soal, tetapi juga menemukan dengan cepat jawaban soal yang sudah tersedia namun masih dalam kondisi acak.

Robert B. Taylor (dalam Huda, 2013: 303), "Scramble merupakan salah satu model pembelajaran yand dapat meningkatkan konsentrasi dan kecepatan berpikir siswa." untuk menyusun kembali jawaban yang masih acak, membutuhkan konsentrasi yang tinggi dari siswa. Kecepatan dalam berpikir juga merupakan hal penting dalam pembelajaran Scramble ini, karena siswa akan berlomba-lomba untuk mendapatkan jawaban yang benar secara cepat. Yang dimaksud dengan Scramble adalah sebuah permainan yang dapat dilakukan oleh 3 atau 5 orang dalam satu kelompok, 
dalam permainan tersebut para pemainnya harus menyusun kembali kata-kata dari huruf-huruf, kalimat dari kata-kata, dan wacana dari potongan kalimat-kalimat yang susunannya telah diacak terlebih dahulu. Teknik ini digunakan untuk sejenis permainan anak-anak.

Berdasarkan uraian tersebut dapat disimpulkan bahwa model pembelajaran Kooperatif tipe Scramble adalah model pembelajaran dengan membagi siswa menjadi kelompok untuk menemukan jawaban dari huruf atau katayang acak, yang digunakan dalam model Scramble, tujuan dari pembelajaran Scramble adalah untuk merangsang siswa berpikir secara kritis dan cepat. Selain itu juga melatih konsentrasi siswa dan kerja sama dalam kelompok. Dengan digunakannya model yang teraplikasi seperti sebuah permainan ini juga akan membuat siswa merasa seanga dan termotivasi dalam pembelajaran.

Menurut Huda (2013: 304) model pembelajaran Scramble mempunyai kelebihan dan kekurangan sebagai model pembelajaran, yaitu sebagai berikut;

a. Kelebihan

1) Setiap anggota kelompok bertanggung jawab atas segala sesuatu yang dikerjakan dalam kelompoknya, setiap anggota kelompok harus mengetahui bahwa semua anggota kelompok mempuyai tujuan yang sama, setiap anggota kelompok harus membagi tugas dan tanggung jawab yang sama di antara anggota kelompoknya, setiap anggota kelompok akan dikenai evaluasi, setiap anggota kelompok berbagi kepemimpinan dan membutuhkan keterampilan untuk belajar bersama selama proses belajarnya, dan setiap anggota kelompok akan diminta pertanggung jawaban secara individual materi yang ditangan dalam kelompok, sehingga individu di kelompok diberi tanggung jawab akan keberhasilan kelompoknya.

2) Metode pembelajaran ini akan memungkinkan siswa untuk belajar sambal bermain. Mereka dapat berkreasi sekaligus belajar dan berfikir, mempelajari sesuatu secara santai dan tidak membuatnya stres atau tertekan.

3) Selain untuk menimbulkan kegembiraan dan melatih keterampilan tertentu, metode Scramble juga dapat memupuk rasa solidaritas dalam kelompok.

4) Materi yang diberikan melalui salah satu metode permainan ini biasanya mengesankan dan sulit untuk dilupakan.

5) Sifat kompetitif dalam metode ini dapat mendorong siswa berlomba-lomba untuk maju. b. Kekurangan

1) Pembelajaran ini terkadang sulit dala merencanakannya, oleh karena terbentur dengan kebiasaan siswa dalam mengajar.

2) Terkadang dalam mengimplementasikannya, memerlukan waktu yang panjang sehingga guru sulit menyesuaikannya dengan waktu yang telah ditentukan.

3) Selama kriteria keberhasilan belajar ditentukan oleh kemampuan siswa menguasai materi pelajaran, maka pembelajaran ini akan sulilt di implementasikan oleh guru.

4) Metode permainan seperti ini biasanya menimbulkan suara gaduh. Hal tersebut jelas akan menggangu kelas yang brdekatan.

Langkah-langkah model pembelajaran kooperatif tipe scramble menurut Huda (2013: 304) adalah sebagai berikut: a) Guru menyiapkan sebuah wacana, kemudian keluarkan kalimat-kallimat yang terdapat dalam wacana tersebut ke dalam kartu-kartu kalimat. b) Guru membuat kartu soal beserta kartu jawaban yang diacak nomornya sesuai materi bahan ajar teks yang telah dibagikan sebelumnya dan membagikan kartu soal tersebut. c) Siswa dalam kelompok masingmasing mengerjakan soal dan mencari kartu soal untuk jawaban yang cocok sebelumnya jawaban telah diacak sedemikian rupa. d) Siswa di haruskan dapat menyusun kata jawaban yang telah tersedia dalam waktu yang telah ditentukan. Setelah selesai mengerjakan soal, hasil pekerjaan siswa dikumpulkan dan dilakukan pemeriksaan.

\section{Minat Belajar}

Minat besar pengaruhnya terhadap yang dilakukan seseorang. Dengan adanya minat seseorang akan melakukan suatu dengan rasa senang dan penuh perhatian, namun sebaliknya jika tanpa dilandasi minat maka seseorang akan merasa enggan atau bahkan malas untuk melakukan sesuatu, hal ini menunjukan bahwa minat merupakan suatu elemen penting untuk mencapai kesuksesan dalam pengerjaan suatu tugas atau kegiatan.

Sardiman (2011:76) menyatakan bahwa: "Pengertian Minat diartikan sebagai suatu kondisi yang terjadi apabila seseorang melihat ciri-ciri atau arti sementara situasi yang dhubungkan dengan keinginan-keinginan atau kebutuhannya sendiri. Oleh karena itu, apa yang dilihat seseorang sudah tentu akan membangkitkan minatnya sejauh apa yang dilihat itu mempunyai hubungan dengan kepentingannya sendiri. Hal ini menunjukkan bahwa minat merupakan kecenderungan jiwa seseorang kepada seseorang (bisanya disertai dengan perasaan senang), karena merasa ada kepentingan dengan sesuatu itu. 
Keberhasilan proses kegiatan belajar dan pembelajaran, selain dipengaruhi oleh faktor guru juga dipengaruhi oleh faktor siswa itu sendiri. Tingkah laku siswa ketika mengikuti proses pembelajaran dapat mengindikasikan akan ketertarikan siswa tersebut terhadap pembelajaran itu atau sebaliknya, ia merasa tidak tertarik dengan pembelajaran tersebut. Ketertarikan siswa inilah yang sering dikenal dengan istilah minat. Sardiman (2011:76) menyatakan bahwa: "Pengertian Minat diartikan sebagai suatu kondisi yang terjadi apabila seseorang melihat ciri-ciri atau arti sementara situasi yang dhubungkan dengan keinginan-keinginan atau kebutuhannya sendiri. Oleh karena itu, apa yang dilihat seseorang sudah tentu akan membangkitkan minatnya sejauh apa yang dilihat itu mempunyai hubungan dengan kepentingannya sendiri. Hal ini menunjukkan bahwa minat merupakan kecenderungan jiwa seseorang kepada seseorang (bisanya disertai dengan perasaan senang), karena merasa ada kepentingan dengan sesuatu itu". Menurut Syaiful Bahri Djamarah (2011:132) Minat adalah kecenderungan yang menetap untuk memperhatikan dan mengenang beberapa aktivitas. Seseorang yang berminat terhadap aktivitas akan memperhatikan aktivitas itu secara konsisten dengan rasa senang." Sedangkan menurut Slameto (2010:180) menyatakan bahwa Minat adalah suatu rasa lebih suka dan rasa ketertarikan pada suatu hal atau aktivitas, tanpa ada yang menyuruh.

Dari pernyataan diatas dapat disimpulkan bahwa seseorang yang berminat terhadap suatu aktivitas akan memperhatikan aktivitas itu secara konsisten dengan rasa senang dikarenakan hal tersebut datang dari dalam diri seseorang yang didasarkan rasa suka dan tidak adanya paksaan dari pihak luar. Dengan kata lain, minat adalah suatu rasa lebih suka dan rasa keterikatan pada suatu hal atau aktivitas, tanpa ada yang memaksa.

\section{Pembelajaran IPA}

Ilmu pengetahuan alam atau sains (science) diambail dari kata latin Scientia yang arti harfiahnya adalah pengetahuan, seperti yang telah dirumuskan Sund dan Trowbribge bahwa sains adalah kumpulan pengetahuan dan proses. Sedangkan Kuslan Stone menyebutkan bahwa Sains adalah kumpulan pengetahuan dan cara-cara untuk mendapatkan dan mempergunakan pengetahuan itu. Sains merupakan produk dan proses yang tidak dapat dipisahkan . "Read Science is both and process, inseparably Joint" Agus. S dalam Wikipedia (2013).

(Puskur, 2009) menyatakan bahwa Ilmu Pengetahuan Alam (IPA) berkaitan dengan cara mencari tahu tentang alam secara sistematis, sehingga IPA bukan hanya penguasaan kumpulan pengetahuan yang berupa fakta-fakta, konsepkonsep, atau prinsip-prinsip saja tetapi juga merupakan suatu proses penemuan.Menurut H.W Flowler dalam (Trianto, 2012) IPA adalah pengetahuan yang sudah sistematis, tersusun dan dirumuskan yang berdasarkan pada pengamatan ataupun dedukasi, serta berkaitan dengan gejalagejala kebendaan.

Berdasarkan pengertian diatas, dapat disampulkan bahwa IPA merupakan kumpulan teori sistematis yang meliputi penguasaan konsep, fakta, prinsip yang menuntut sikap ilmiah dan hasilnya terwujud dalam produk ilmiah.

Laksmi (Trianto, 2012: 142) mengungkapkan bahwa pembelajaran IPA di sekolah mempunyai tujuan-tujuan tertentu, yaitu: 1) Memberikan pengetahuan kepada siswa tentang dunia tempat hidup dan bagaimana bersikap, 2) Menanamkan sikap hidup ilmiah, 3) Memberikan ketrampilan untuk melakukan pengamatan, 4) Mendidik siswa untuk melakukan pengamatan, 5) Membidik siswa untuk mengenal, mengetahui cara kerja serta menghargai para ilmuwan penemunya, dan 6) Menggunakan dan menerapkan metode ilmiah dalam memecahkan permasalahan.

\section{Hasil Penelitian Relevan}

Penelitian yang dilakukan oleh Febri Belandina L. (2010) menunjukkan adanya peningkatan minat belajar. Hasil penelitian yang diperoleh adalah sebagai berikut : presentase minat belajar siswa sebesar 51, $53 \%$ dalam kategori cukup sedangkan pada siklus II sebesar 67, 12 \% dalam kategori baik. Dengan melihat pada presentase minat belajar siswa pada siklus II presentase minat belajar siswa mengalami peningkatan. Disimpulkan bahwa model pembelajaran Scramble ini dapat meningkatkan minat belajar PKn siswa kelas VA SDN Madyopura 4 Kota Malang.

Begitu juga dengan penelitian yang dilakukan oleh Kristianti (2011) di SDN Keting 01 Jombang Kabupaten Jember pada siklus I, presentase minat belajar siswa sebesar 46, $63 \%$ dalam kategori cukup sedangkan pada siklus II sebesar 62, $02 \%$ dalam baik. Kesimpulan dari penelitian ini adalah siswa mengalami peningkatan minat belajar pada pokok pembahasan kenampakan alam dan sosial budaya. Oleh karena itu penelitian di SDN Keting o1 Jombang Kabupaten Jember tuntas. Saran untuk penelitian ini adalah model pembelajaran kooperatif tipe Scramble dapat digunakan sebagai model alternatif untuk mengembangkan model pembelajaran IPS.

Penelitian yang dilakukan penulis memiliki kesamaan dengan penelitian yang telah dilakukan diatas. Penelitian ini memiliki objek penelitian yaitu 
peningkatan minat belajar yang akan dilakukan dengan model kooperatif tipe Scramble.

\section{METODE PENELITIAN}

Penelitian ini berbentuk Penelitian Tindakan Kelas (Classroom Action Research). Hopkins ( dala Rochiati Wiriaatmadja, 2007: 11) menyatakan bahwa penelitian tindakan kelas adalah sebuah penelitian yang mengkombinasikan prosedur penelitian dengan tingkat substansif, atau suatu usaha seseorang untuk memahami apa yang sedang terjadi sambbil terlibat dalam sebuah proses perbaikan dan perubahan.

Penelitian ini dilakukan di kelas V SDN Salatiga o9 yang beralamatkan di Jalan Diponegoro No 12 Salatiga, Kecamatan Sidorejo, Kota Salatiga tahun pelajaran 2017/2018. Kepala sekolah dijabat oleh Bangun Setiani, S.Pd yang membawahi 10 orang guru dan tenaga administrasi, 6 orang bertindak sebagai guru kelas, 1 orang bertindak sebagai guru mata pelajaran agama Islam, 1 orang sebagai guru olah raga, dan 2 orang sebagai tenaga administrasi. Sekolah ini memiliki 6 ruang kelas, 1 ruang yang menjadi satu : kepala sekolah, ruang guru, ruang UKS dan ruang tamu, 1 ruang perpustakaan yang menjadi satu dengan ruang administrasi, 1 ruang dapur, 1 gudang, rumah dinas, 4 kamar mandi siswa. Alasan pemilihan SDN Salatiga o9 sebagai lokasi penelitian adalah karena peneliti ingin memperbaiki pola pembelajaran di kelas agar minat siswa terhadap pelajaran tematik tinggi.

Siswa kelas V terdiri dari 43 orang, 22 siswa perempuan dan 21 siswa laki-laki. Sebagian besar pekerjaan orang tua siswa adalah buruh dan pegawai, karena kesibukannya mencari nafkah mereka tidak sempat mengurus anaknya dan juga fasilitas yang disediakan sangat minim. Siswa menjadi kurang perhatian terhadap pelajaran dan asik bermain sesuka hatinya.

Teknik pengumpulan data variabel model pembelajaran kooperatif tipe Scramble menggunakan teknik non tes yaitu observasi. Observasi yaitu metode atau cara-cara yang menganalisis dan mengadakan pencatatan secara sistematis mengenai tingkah laku dengan melihat atau mengamati individu atau kelompok secara langsung. Observasi dalam penelitian ini digunakan untuk mengamati respon siswa dan tindakan guru dalam menerapkan pembelajaran dengan model Scramble. Sehingga dapat dilihat pelaksanaan pembelajaran benar-benar sesuai dengan kondisi dan proses yang diharapkan. Observasi dilakukan oleh guru kolaborator selama proses pembelajaran berlangsung. Pada tahap ini, observer melakukan pengamatan dan mencatat semua hal-hal yang diperlukan dan terjadi selama pelaksanaan tindakan berlangsung.

Untuk mengumpulkan variabel minat belajar digunakan teknik tes dan juga pemberian angket. Guru memberi tes sebagai sarana mengevaluasi siswa untuk mengukur tingkat keberhasilan belajar siswa. Minat belajar siswa nantinya dapat diukur dengan mengacu hasil tes yang dikerjakan siswa, karena semakin tinggi minat siswa maka semakin baik juga hasil tes siswa. Pemberian angket untuk mengetahui data variabel penelitian yaitu minat belajar. Minat terhadap pembelajaran tematik adalah ketertarikan siswa terhadap tematik didasarkan pada kegunaannya yang diperlukan untuk kebutuhan dalam dirinya. Semakin kuat kebutuhan ini, semakin kuat dan bertahan minat itu. Sehingga semakin sering minat itu diekspresikan maka semakin kuatlah dia.

\section{HASIL DAN PEMBAHASAN}

\section{Kondisi Pra Siklus}

Sebelum proses penelitian dilaksanakan, terlebih dahulu peneliti mengadakan kegiatan pra siklus pada bulan Maret 2018. Kegiatan ini dilakukan dengan tujuan menyampaikan maksud untuk mengadakan penelitian tindakan kelas dengan menerapkan model pembelajaraan kooperatif tipe scramble untuk meningkatkan minat belajar. Pengumpulan data ini bertujuan untuk mengetahui pandangan awal minat belajar selama ini.

Untuk mendapatkan data minat siswa terhadap mata pelajaran IPA, telah disediakan angket yang disiapkan sebelumnya. Data angket dapat dilihat pada tabel dibawah ini.

TABEL 1

SKOR ANGKA MINAT BELAJAR MUPEL IPA PRA SIKLUS

\begin{tabular}{|c|c|c|c|c|}
\hline $\mathrm{N}$ & Interval & Kategori & $\begin{array}{c}\text { Frekuen } \\
\text { si }\end{array}$ & $\begin{array}{c}\text { Presentasi } \\
(\%)\end{array}$ \\
\hline 1 & $21-38$ & Sangat Kurang & 3 & $6,70 \%$ \\
2 & $39-56$ & Kurang & 10 & $23,30 \%$ \\
3 & $57-74$ & Cukup & 8 & $18,64 \%$ \\
4 & $75-91$ & Baik & 14 & $32,72 \%$ \\
5 & $92-105$ & Sangat Baik & 8 & $18,64 \%$ \\
\hline \multicolumn{2}{|c|}{ Jumlah } & 43 & $100 \%$ \\
\hline Rata-rata hasil angket minat & \multicolumn{2}{|c|}{$69,38 \%$} \\
\hline \multicolumn{2}{|c|}{ Skor angket minat tertinggi } & \multicolumn{2}{|c|}{100} \\
\hline \multicolumn{2}{|c|}{ Skor angket minat terendah } & \multicolumn{2}{|c|}{30} \\
\hline
\end{tabular}

Data Tabel 1 dapat dilihat bahwa siswa yang masuk kategori sangat kurang 3 siswa atau 6,70\%, kategori kurang 10 siswa atau $23,30 \%$, kategori cukup 8 siswa atau $18,64 \%$, kategori baik 14 siswa atau $32,72 \%$, dan kategori sangat baik 8 siswa atau $18,64 \%$. Rata-rata hasil angket siswa $69,38 \%$ dalam kategori cukup. Dari data persentase minat siswa diatas dapat digambarkan dalam diagram lingkaran sebagai berikut: 


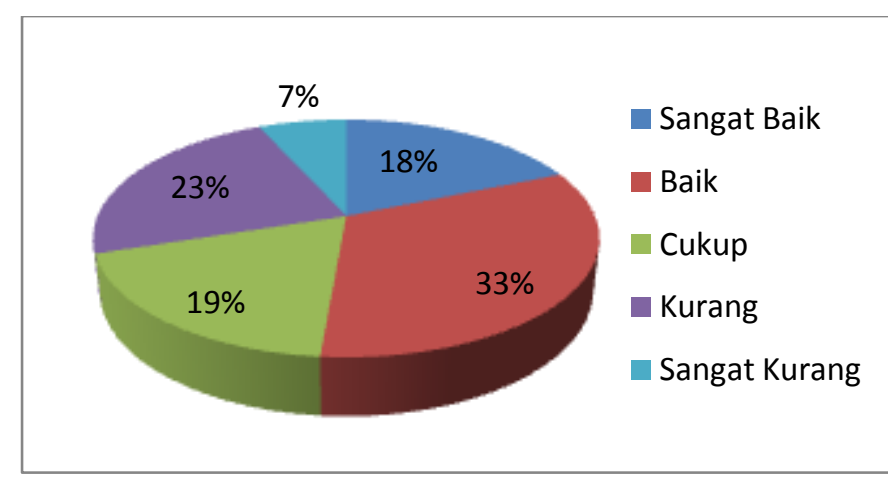

Diagram 1. Skor Angka Minat Belajar Mupel IPA Pra Siklus

Dari diagram lingkaran diatas dapat dilihat bahwa siswa yang mempuyai minat terhadap muatan pelajaran IPA dalam kategori sangat baik mencapai $18 \%$, kategori baik 33\%, kategori cukup 19\%, kategori kurang $23 \%$, dan kategori sangat kurang $7 \%$.

\section{Siklus I}

Pada tahap ini peneliti berkoordinasi dengan guru mengenai pembelajaran yang akan dilakukan serta bahan pendukung dalam pembelajaran. Kegiatan belajar mengajar siklus 1 akan berlangsung sebanyak 2 kali pertemuan. Data minat siswa diperoleh dari angket yang dibagikan kepada siswa di pertemuan II. Data yang diperoleh dapat dilihat pada tabel dibawah ini.

TABEL 2

SKOR ANGKA MINAT BELAJAR MUPEL IPA SIKLUS I

\begin{tabular}{|c|c|c|c|c|}
\hline $\begin{array}{c}\mathrm{N} \\
\mathrm{o}\end{array}$ & Interval & Kategori & $\begin{array}{c}\text { Frekuen } \\
\text { si }\end{array}$ & $\begin{array}{c}\text { Presentasi } \\
(\%)\end{array}$ \\
\hline 1 & $21-38$ & Sangat Kurang & 1 & $2,32 \%$ \\
2 & $39-56$ & Kurang & 8 & $18,28 \%$ \\
3 & $57-74$ & Cukup & 14 & $33,90 \%$ \\
4 & $75-91$ & Baik & 12 & $26,90 \%$ \\
5 & $92-105$ & Sangat Baik & 8 & $18,60 \%$ \\
\hline \multicolumn{2}{|c|}{ Jumlah } & 43 & $100 \%$ \\
\hline \multicolumn{2}{|c|}{ Rata-rata hasil angket minat } & \multicolumn{2}{|c|}{$72,40 \%$} \\
\hline \multicolumn{2}{|c|}{ Skor angket minat tertinggi } & \multicolumn{2}{c|}{100} \\
\hline \multicolumn{2}{|c|}{ Skor angket minat terendah } & \multicolumn{2}{c|}{35} \\
\hline
\end{tabular}

Dari tabel 2 dapat dilihat siswa yang masuk dalam kategori sangat kurang menjadi 1 atau 2,32\%, kategori kurang 8 siswa atau 18,28\%, kategori cukup 15 siswa atau $33,90 \%$, kategori baik 12 siswa atau 26,90 dan aktegori sangat baik 8 siswa atau 18,60. Rata-rata hasil angket minat siswa meningkat dari hasil pra siklus yaitu 72,40 dalam kategori cukup, skor tertinggi mencapai 100 dan terendah 35. Berdasarkan presentase tabel dapat dibuat diagram lingkaran dibawah ini

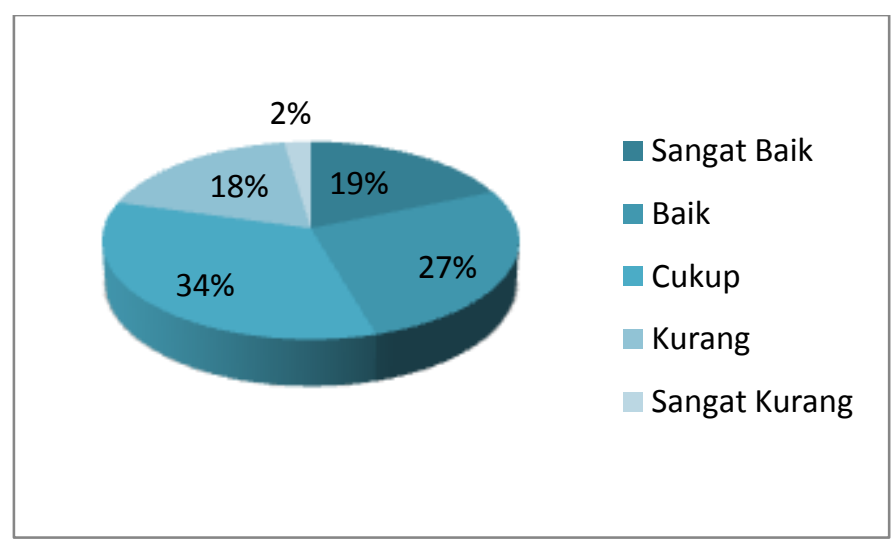

Diagram 2. Skor Angket Minat Belajar Mupel IPA Siklus 1

Berdasarkan diagram 4.2 dapat dilihat jelas bahwa siswa yang masuk kategori sangat kurang $2 \%$, kategori kurang 18\%, kategori cukup 34\%, kategori baik 27\%, dan kategori sangat baik 19\%. Dapat diamati bahwa setelah penerapan model kooperatif tipe scramble pada siklus I minat siswa terhadap muatan pelajaran IPA meningkat dibandingkan minat belajar IPA saat pra siklus terlihat dari skor siswa yang mendapatkan kategori sangat kurang menjadi lebih sedikit.

\section{Siklus II}

Pada tahap ini pembelajaran masih dilakuakan dengan 2 kali pertemuan dan pada pertemuan II peneliti memberikan angket minat untuk mengukur minat belajar siswa. Data pada siklus II ini dapat dilihat pada tabel dibawah.

\section{TABEL 3}

SKOR ANGKA MINAT BELAJAR MUPEL IPA SIKLUS II

\begin{tabular}{|c|c|c|c|c|}
\hline $\mathrm{N}$ & Interval & Kategori & $\begin{array}{c}\text { Frekuen } \\
\text { si }\end{array}$ & $\begin{array}{c}\text { Presentasi } \\
(\%)\end{array}$ \\
\hline 1 & $21-38$ & Sangat Kurang & o & O\% \\
2 & $39-56$ & Kurang & 5 & $11,62 \%$ \\
3 & $57-74$ & Cukup & 9 & $21 \%$ \\
4 & $75-91$ & Baik & 19 & $44,18 \%$ \\
5 & $92-105$ & Sangat Baik & 10 & $23,20 \%$ \\
\hline \multicolumn{2}{|c|}{ Jumlah } & 43 & $100 \%$ \\
\hline Rata-rata hasil angket minat & \multicolumn{2}{|c|}{$89,75 \%$} \\
\hline Skor angket minat tertinggi & \multicolumn{2}{|c|}{100} \\
\hline Skor angket minat terendah & \multicolumn{2}{|c|}{50} \\
\hline
\end{tabular}

Pada tabel 3 kategori kurang ada 5 siswa atau $11,62 \%$, kategori cukup 9 siswa atau $21 \%$, kategori baik ada 19 siswa atau $44,18 \%$, dan kategori sangat baik ada 10 siswa atau $23,20 \%$. Rata-rata meningkat daripada hasil siklus I menjadi 89,75\% dalam kategori baik, skor angket tertinggi 100 dan terendah 50. Dari data presentase minat belajar siswa diatas dapat digambarkan pada diagram dibawah ini. 


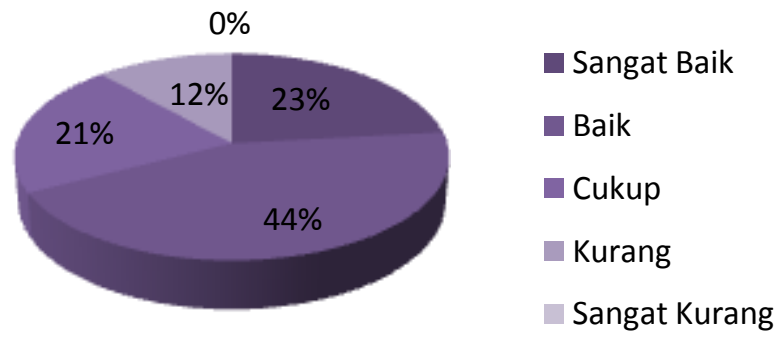

Diagram 3. Skor Angket Minat Belajar Mupel IPA Siklus Ii

Dari diagaram lingkaran 4.3 diatas dapat dillihat siswa yang masuk kategori kurang ada 5 siswa atau $12 \%$, kategori, kategori cukup ada 9 siswa atau $21 \%$, kategori baik ada 19 siswa atau 44\%, dan kategori sangat baik ada 10 siswa atau 23\%. Dari data tersebut dapat dilihat bahwa penerapan model pembelajaran kooperatif tipe scramble pada muatan pelajaran IPA meningkatkan minat belajar siswa sehingga indicator kinerja yang ditetapkan tercapai.

\section{Hasil Analisis Data}

Pelaksanaan dimulai sebelum peneliti menerapkan model pembelajaran yang disebut pra siklus. Hasil dari minat ini dapat dijadikan bahan acuan dalam perencanaan pembelajaran saat peneliti melakukan penelitian. Pengukuran minat selanjutnya pada siklus I dan siklus II saat akhir pertemuan. Rekapitulasi hasil data yang diperoleh dari pra siklus, siklus I, dan siklus II dapat dilihat pada tabel 4.

TABEL 4

REKAPITULASI SKOR ANGKA MINAT BELAJAR IPA PRA SIKLUS, SIKLUS I, DAN SIKLUS II

\begin{tabular}{|c|c|c|c|c|c|c|}
\hline \multirow[b]{2}{*}{ Kategori } & \multicolumn{3}{|c|}{ Frekuensi } & \multicolumn{3}{|c|}{ Persentasi } \\
\hline & $\begin{array}{c}\text { Pra } \\
\text { Sikl } \\
\text { us }\end{array}$ & $\begin{array}{c}\text { Sik } \\
\text { lus } \\
\text { I }\end{array}$ & $\begin{array}{c}\text { Sikl } \\
\text { us II }\end{array}$ & $\begin{array}{c}\text { Pra } \\
\text { Siklus }\end{array}$ & Siklus I & $\begin{array}{c}\text { Sikl } \\
\text { us } \\
\text { II }\end{array}$ \\
\hline $\begin{array}{l}\text { Sangat } \\
\text { Kurang }\end{array}$ & 3 & 1 & 0 & $6,70 \%$ & $2,32 \%$ & 0 \\
\hline Kurang & 10 & 8 & 5 & $23,30 \%$ & $18,28 \%$ & 11,6 \\
\hline Cukup & 8 & 14 & 9 & $18,64 \%$ & $33,90 \%$ & $21 \%$ \\
\hline Baik & 14 & 12 & 19 & $32,72 \%$ & $26,90 \%$ & $\begin{array}{c}44,1 \\
8 \%\end{array}$ \\
\hline $\begin{array}{c}\text { Sangat } \\
\text { Baik }\end{array}$ & 8 & 8 & 10 & $18,64 \%$ & $18,60 \%$ & $\begin{array}{c}23 \\
20 \\
\%\end{array}$ \\
\hline Jumlah & 43 & 43 & 43 & $\begin{array}{c}100,00 \\
\%\end{array}$ & $\begin{array}{c}100,00 \\
\%\end{array}$ & $\begin{array}{c}100, \\
00 \\
\%\end{array}$ \\
\hline
\end{tabular}

Dari tabel diatas dapat dilihat peningkatan siswa yang mempuyai minat belajar pada muatan pelajaran IPA. Pada pra siklus siswa masuk kategori sangat kurang 3 siswa atau 6,70\%, kategori kurang 10 siswa atau 23,30\%, kategori cukup 8 siswa atau 18,64\%, kategori baik 14 siswa atau 32,72\%, dan kategori sangat baik 8 siswa atau 18,64\%. Setelah peneliti menerapkan tindakan terjadi peningkatan minat siklus I, terjadi penurunan angka pada kategori sangat kurang, kurang, dan baik sementara untuk kategori cukup mengalami peningkatan angka dan pada kategori sangat baik masih memperoleh angka yang sama. Pada kategori sangat kurang yang semula 3 siswa menjadi 1 siswa atau 2,32\%, kategori kurang yang semula 10 siswa menjadi 8 siswa atau $18,28 \%$, dan kategori baik yang semula 14 siswa menjadi 12 siswa atau 26,90\%. Untuk kategori cukup yang semula 8 siswa menjadi 14 siswa atau 33,90\% dan kategori sangat baik masih sama 8 siswa atau 18,60\%. Sama halnya pada siklus II juga mengalami peningkatan. Penurunan angka terjadi pada kategori sangat kurang, kurang, dan cukup, sementara pada kategori baik dan sangat baik mengalami peningkatan. Untuk kategori sangat kurang yang semula ada 1 siswa menjadi o, kategori kurang semula 8 siswa menjadi 5 siswa atau 11,62\%, kategori cukup semula 14 siswa menjadi 9 siswa atau 21\%. Sementara itu pada kategori baik semula 12 siswa menjadi 19 siswa atau 44,18\%, dan kategori sangat baik semula 8 siswa menjadi 10 siswa atau 23,20\%. Dari data tersebut dapat disimpulkan penerapan model pembelajaran kooperatif tipe scramble dapat meningkatkan minat belajar mupel IPA siswa kelas V SDN Salatiga o9. Perbandingan hasil dapat dilihat pada diagram dibawah ini:

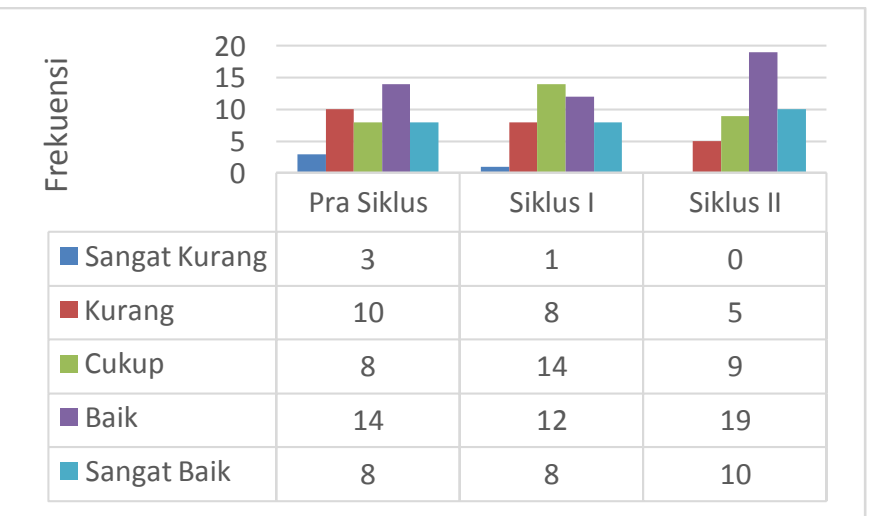

Diagram 4. Rekapitulasi Skor Angka Minat Belajar Mupel IPA Pra Siklus, Siklus I, Dan Siklus Ii

Pada diagram diatas terlihat perbandingan jumlah siswa yang minat dan kurang minat terhadap muatan pelajaran IPA. Pada kondisi pra siklus siswa yang masuk kategori sangat kurang 3 siswa, kategori kurang 10 siswa, kategori cukup 8 siswa, kategori baik 14 siswa, dan kategori sangat baik 8 siswa. Setelah mendapatkan tindakan dari peneliti pada siklus I mengalami pemingkatan berupa penurunan pada kategori sangat kurang yang semula 3 siswa menjadi 1 siswa, kategori kurang adri 10 siswa menjadi 8 siswa, kategori baik dari 14 siswa menjadi 12 siswa. Sementara untuk kategori cukup mengalami peningkatan dari 8 siswa menjadi 14 siswa dan kategori sangat baik masih sama 8 siswa. Peningkatan 
juga terjadi pada siklus II yaitu penurunan yang terjadi pada kategori sangat kurang yang semula 1 siswa menjadi o siswa, kategori kurang semula 8 siswa menjadi 5 siswa, kategori cukup semula 14 siswa menjadi 9 siswa. Sementara untuk kategori baik dan sangat baik mengalami peningkatan yaitu dari 12 siswa menjadi 19 siswa untuk kategori baik, dan kategori sangat baik semula 12 siswa menjadi 19 siswa. Dari kondisi tersebut terjadi peningkatan siswa yang minat terhadap muatan pelajaran IPA dan penurunan siswa yang kurang minat pada muatan pelajaran IPA.

\section{Pembahasan}

Sebelum melakukan penelitian, peneliti melakukan observasi terlebih dahulu di SDN Salatiga o9 Kecamatan Sidorejo Kota Salatiga. Pada observasi ini peneliti melihat keadaan siswa pada saat proses pembelajaran. Pada saat pembelajaran banyak siswa yang berbicara sendiri dan tidak memperhatikan guru yang mengajar didepan. Perhatian siswa terhadap pelajaran masih kurang. Sehingga dapat disimpulkan bahwa minat belajar siswa sangat kurang hal ini didukung oleh hasil angket pada saat pra siklus yang diperoleh rata-rata 69,38\% dalam kategori cukup.

Berdasarkan data observasi yang telah dikumpulkan sebelumnya, maka peneliti tergerak untuk meningkatkan minat belajar tema 8 mupel IPA siswa kelas V SDN Salatiga o9 dengan menerapkan model pembelajaran kooperatif tipe scramble. Model ini dipilih karena memiliki keunggulan dalam hal latihan soal yang dibuat lebih menarik.

Sebelum melakukan pembelajaran peneliti telah mempersiapkan instrument pembelajaran yang berkaitan dengan indikator yang telah ditetapkan. Pada siklus I penerapan model pembelajaraan kooperatif tipe scramble masih banyak kekurangan yang perlu diperbaiki oleh peneliti. Pada pertemuan I peneliti belum berhasil menarik semua perhatian siswa sehingga banyak siswa yang belum siap untuk belajar mereka lebih asik berbicara sendiri dan bermain. Pada kegiatan inti siswa belum antusias dalam mengikuti pemeblejaran, mereka cenderung asik berbicara sendiri dan kurang konsentrasi. Skor hasil observasi pada pertemuan ini yang diperoleh 23 dan masuk dalam ketgori cukup. Di pertemuan ke II peneliti berusaha memperbaiki kekurangan pada pertemuan sebelumnya. Peneliti berusaha lebih menarik perhatian siswa dengan meminta siswa untuk mempresentasikan hasil diskusi mereka didepan kelas dan memberikan kesempatan kepada teman sejawatny untuk mengemukakan pendapatnya. Cara ini cukup efektif dalam menarik perhatian siswa, namun masih ada beberapa siswa yang belum siap belajar, siswa masih malu-malu dalam menyampaikan pendapat mereka. Dan ketika guru meminta siswa untuk berdiskusi masih ada anggota kelompok yang menyontek pekerjaan kelompok lain sehingga kegiatan diskusi menjadi kurang kondusif dan kurang adil bagi kelompok lainnnya. Antusias siswa sudah Nampak tinggi ketika siswa bertukar pendapat dan pembelajaran di pertemuan ke II ini berjalan baik dan lancer. Skor yang didapatkan pada pertemuan ke II ini meningkat menjadi 27 dan masuk dalam kategori baik. Sebelum menutup pelajaran peneliti melakukan evaluasi dengan memberikan lembar evaluasi dan angket minat belajar. Hasil rata-rata angket minat belajar pada siklus I ini mencapai $72,40 \%$ masuk dalam kategori baik. Data ini menunjukkan kenaikan presentase minat siswa yang diperoleh daripada hasil pra siklus, namun perolehan skor ini masih belum memenuhi indicator kinerja yang ditetapkan sebelumnya.

Sebelum melakukan pembelajaran siklus II, peneliti melakuakan refleksi atas tindakan pada siklus I. Perbaika dilakukan agar pembelajaran pada siklus II ini meningkatkan minat belajar siswa. Dalam pertemuan I peneliti masih menggunakan strategi yang sama pada siklus I namun peneliti menambahkan hal yaitu ketegasan dalam pembelajaran dan interaksi dengan siswa lebih ditekankan. Pembelajaran berjalan secara kondusif, semua siswa sudah mulai menunjukkan perhatiannya sejak kegiatan awal, inti, hingga penutup. Siswa sudah mulai berani bertanya dan menjawab pertanyaan dari peneliti. Dalam kegiatan diskusi siswa sudah menaati peraturan yang telah ditetapkan oleh peneliti. Skor observasi guru yang diperoleh 34 dan masuk dalam kategori sangat baik. Pada pertemuan II rencana yang digunakan masih sama dengan pertemuan I karena pembelajaran pada pertemuan I sudah berjalan baik. Kondisi pembelajaran pada pertemuan II sangat kondusif, siswa sudah mulai terbiasa dengan model pembelajaran yang diterapkan oleh peneliti. Skor yang diperoleh pada pertemuan kali ini adalah 36 dan masuk dalam kategori sangat baik. Sebelum peneliti menutup pembelajaran, siswa kembali diberikan lembar evaluasi dan angket minat belajar untuk mengukur keberhasilan tindakan yang dilakukan peneliti. Data minat belajar siswa setelah penerapan model kooperatif tipe scramble pada siklus II mendapatkan rata-rata $89,75 \%$ dan masuk dalam kategori baik.

Dari data observasi siswa, observasi guru, dan angket minat belajar pada pra siklus, siklus I, dan siklus II menunjukkan bahwa telah terjadi peningkatan minat belajar yang telah memenuhi indicator kinerja yang telah di tetapkan. Hal ini dapat terjadi karena penerapan model kooperatif tipe scramble. Menurut Sharan (Isjoni, 2009:43), berpendapat bahwa siswa yang belajar dengan mengguanakan metode pembelajaran kooperatif akan memiliki minat yang tinggi karena didorong dan didukung dari rekan sebaya sehingga hasil belajar juga akan maksimal. Pembelajaran kooperatif juga 
menghasilkan peningkatan kemampuan akademik, meningkatkan kemampuan berfikir kritis, membentuk hubungan persahabatan, menimba berbagai informasi, dan meingkatkan minat siswa, memperbaiki sikap terhadap sekolah dan belajar mengurangi perilaku yang kurang baik. Begitu juga untuk belajar sangat diperlukan adanya minat. Makin tepat minat yang diberikan, maka pembelajaran yang dilaksanakan makin berhasil (Sadirman, 2011:84).

Minat belajar penting artinya dalam proses belajar siswa, karena fungsinya yang mendorong, menggerakkan, dan mengarahkan kegiatan belajar (Oemar Hamalik, 2001). Minat belajar siswa dapat tumbuh dalam pembelajaran yang menyenangkan. Model pembelajaran kooperatif yang dapat digunakan untuk meningkatkan minat belajar siswa salah satunya adalah Scramble. Dengan model kooperatif tipe scramble siswa dapat menyusun jawaban sambal mempelajari konsep atau topik tertentu dalam suasana yang menyenangkan (Miftahul Huda, 2011:135). Dengan semakin meningkatnya minat siswa terhadap muatan pelajaran IPA maka hasil belajar yang akan diperoleh juga maksimal. Scramble dapat diterapkan dalam semua muatan pelajaran yang memuat konsep dan topik materi yang sangat luas. Scramble dapat digunakan untuk meningkatkan minat belajar siswa terhadap muatan pelajaran IPA. Untuk itu bagi guru yang masih menggunakan model konvensional dalam pembelajaran cobalah untuk berinovasi dengan menerapkan pembelajaran kooperatif tipe scramble. Model ini sudah terbukti dapat meningkatkan minat siswa terhadap muatan pelajaran IPA dan mendapatkan hasil belajar yang maksimal.

\section{E. SIMPULAN DAN SARAN}

\section{Simpulan}

Berdasarkan pembahsan diatas dapat disimpulkan bahwa model pembelajaran kooperatif tipe scramble dapat memingkatkan minat belajar tema 8 mupel IPA kelas V SDN Salatiga o9 Kecamatan Sidorejo Kota Salatiga. Peningkatan ini dapat dilihat pada hasil angket minat pada pra siklus mendapatkan rata-rata 69,38\% masuk dalam kategori cukup. Setelah dilakukan tindakan pada siklus I presentase siswa yang berminat belajar mupel IPA mulai bertambah, sehiingga rata-rata yang didapatkan $72,40 \%$ masuk dalam kategori baik. Dari hasil siklus I, peneliti masih melakukan perbaikan dalam pembelajaran dan hasilnya peningkatan ini terus terjadi pada siklus II jumlah siswa yang berminat semakin banyak, siswa mulai tertarik dengan mupel IPA. Sehingga pada siklus ini mendapatkan rata-rata 89,75\% masuk dalam kategori baik.

\section{Saran}

Berdasarkan hasil penelitian yang telah dilakukan, terbukti bahwa dengan penerapan model pembelajaran kooperatif tipe scramble dapat meningkatkan minat belajar siswa, maka peneliti memberikan saran sebagai berikut:

a. Bagi Siswa

1) Bagi siswa yang kurang menyenangi muatan pelajaran IPA, sebaiknya digunakan pembelajaran yang inovatif. Misalnya dengan metode pembelajaran koooperatif tipe scramble.

2) Bagi siswa yang masih mendapatkan nilai evaluasi yang rendah, belajarlah lebih rajin, semangat dan jangan malu bertanya pada teman maupun guru.

3) Untuk melatih siswa dalam kehidupan sosialnya, penerapan model kooperatif tipe scramble dapat menumbuhkan rasa kebersamaan dan kejujuran.

4) Dengan metode pembelajaran kooperatif tipe scramble diharapkan para siswa untuk lebih aktif dan berani bertanya maupun menjawab pertanyaan

b. Bagi Guru

1) Guru diharapkan menggunakan model pembelajaran kooperatif tipe scramble karena terbukti dapat meningkatkan minat belajar siswa.

2) Guru diharapkan mencari inovasi pembelajaran baik model maupun media pembelajaran agar tujuan pembelajaran dapat tercapai dengan baik.

c. Bagi Sekolah

1) Dengan metode pembelajaran kooperatif tipe scramble diharapkan dapat memberi sumbangan yang baik bagi sekolah dalam rangka perbaikan proses pembelajaran guna meningkatkan kualitas pembelajaran.

2) Sekolah sebagai Lembaga Pendidikan agar memotivasi guru untuk mencari inovasi dan menggunakannya dalam pembelajaran sehingga dapat menarik siswa untuk belajar.

\section{UCAPAN TERIMA KASIH}

Penulis mengucapkan terima kasih kepada Allah SWT yang telah memberikan nikmat yang didapat digantikan dengan apapun. Kepada semua pihak yang telah membantu dalam proses penelitian. Teruama kepada orang tua yang selalu memberikan dorongan berupa semangat dan doa, kepada dosen pembimbing dan juga teman - teman. Terima kasih kepada SD N Salatiga o9 yang telah memberikan kesempatan untuk melakukan penelitian. 


\section{DAFTAR RUJUKAN}

[1] AM, S. (2011). Interaksi dan Motivasi Belajar Mengajar. Jakarta: PT Rajagrafindo.

[2] Arikunto, S. (2012). Dasar-dasar Evaluasi Pendidikan. Jakarta: PT Bumi Aksara.

[3] Cahyo N, A. (2013). Panduan Aplikasi Teori-teori Belajar MengajarTeraktual Terpopuler. Jogjakarta: Diva Press.

[4] Djamarah, S. B. (2002). Strategi Belajar Mengajar. Jakarta: Penerbit Rineka Cipta.

[5] Djamarah, S. B. (2011). Psikologi Belajar. Jakarta: PT Rineka Cipta.

[6] Hamalik, O. (2010). Proses Belajar Mengajar. Jakarta: PT Bumi Aksara.

[7] Huda, M. (2013). Model-model Pengajaran dan Pembelajaran. Yogyakarta: Pustaka Pelajar.

[8] Isjoni. (2009). Coopertive Learning Efektivitas Pembelajaran Kelompok. Bandung: Alfabeta.

[9] Kunandar. (2007). Guru Profesional: Implementasi Kurikulum Tingkat Satuan Pendidikan (KTSP) dan Persiapan Menghadapi Sertifikasi Guru. Jakarta: PT Raja Grafindo Persada.

[10] Permendikbud No.21. (2016). Standar Isi Pendidikan Dasar dan Menengah. Jakarta

[11] Permendikbud No. 57. (2014). Kurikullum 2013 SD/M. Jakarta.

[12] Sagala, S. (2003). Konsep dan Makna Pembelajaran. Bandung: Alfabeta.

[13] Slameto. (2012). Penelitian dan Inovasi Pendidikan. Salatiga: Widya Sari Press.

[14] Sugiyono. (2010). Metode Penelitian Pendidikan Pendekatan Kuantitatif Kualitatif dan R\&D. Bandung: Alfabeta.

[15] Suprihatiningrum, J. (2013). Strategi Pembelajaran. Yogyakarta: Ar-ruzz Media.

[16] Suryobroto, D. B. (2009). Proses Belajar Mengajar di Sekolah. Jakarta: Rineka Cipta.

[17] Trianto. (2007). Mendesain Model Pembelajaran Inovatif-Progresif. Jakarta: Kencana Perdana Media Group.

[18] Wardani, N. S. (2012). Asesmen Pembelajaran SD. Salatiga: Wisya Sari.

[19] Wiriaatmadja, R. (2012). Metode Penelitian Tindakan Kelas. Bandung: PT Remaja Rosdakarya.

\section{PROFIL PENULIS UTAMA}

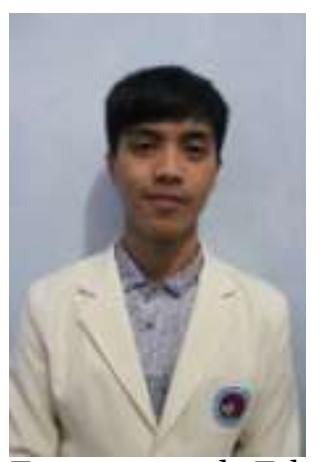

Penulis bernama lengkap FACHRUL IMAMI, lahir di Boyolali 20 April 1996. Penulis tinggal di Desa Kaligentong Kecamatan Ampel Kabupaten Boyolali. Penulis memulai pendidikan pertamanya di SDN Kaligentong 2 pada tahun 2002 2008, kemudian di SMP N Ampel 1 pada tahun 2008 - 2011, kemudian melanjutkan di SMK N Tengaran 1 pada Tahun 20011 - 2014, kemudian masuk pada jenjang perguruan tinggi pada tahun 2014. Segala kritik dan saran yang membangun bisa dikirim ke email penulis di : fachrul551@gmail.com 